\title{
ASSESSMENT OF COMPETITIVENESS OF POWER GENERATING COMPANIES THROUGH A RISK- BASED APPROACH: A CASE STUDY OF DEVELOPING ECONOMIES
}

\author{
G. CHEBOTAREVA \& A. DOMNIKOV \\ Department of banking and investment management, Ural Federal University, Russia.
}

\begin{abstract}
The global financial crisis has shown that power companies are highly exposed to market risks. Market volatility creates competitive tension in the industry because the lack of the necessary methodological tools does not allow power companies to timely identify and measure the severity of emerging threats. Given the current situation, one of the major challenges in the industry is the creation of tools able to assist in the development of a strategy for improving the competitiveness of power companies. The article presents the authors' risk-based approach to the assessment of industrial risks in the power sector. It assumes a certain level of long-term financial stability, investment attractiveness and, as a result, the competitiveness of the company. The aspects of practical application of the authors' approach to the assessment of industrial risks are shown in examples of power companies.

Keywords: (Value at Risk) VaR methodology, competitiveness, development strategy, economic capital, investment attractiveness, investments, long-term financial stability, market risk, power business, power company, risk cost.
\end{abstract}

\section{INTRODUCTION}

During economic and political instability an important factor in the industrial growth of any nation, including emerging economies, is a stable and rapid development of its power sector. Mainly, the power costs represent one of the key indicators that have a significant impact on the cost structure of final goods and services of industrial corporations. Therefore, a high level of depreciation of equipment, high cost of primary resources, the lack of market competition in the sector and other factors determining the low efficiency of most power companies in developing economies, largely underline the lack of capacity for rapid and sustainable growth of industrial production $[1,2]$.

One of the ways of solving this problem is the implementation of comprehensive investment programs for implementation of resource - and power-efficient technologies in the power sector companies. This will not only increase the productivity of companies, but in the long term will allow to achieve sustainable development of the whole sector.

However, the process of implementing such investment policies with a high probability would face a significant number of destabilizing factors in the form of both investment and industry risks. Combined with market threats, they can have a negative impact on the competitiveness of the whole sector. Many years of research carried out by the authors in this field [1,3-7] has shown that the assessment of emerging risks should accompany the development of specific mathematical apparatus that accounts not only for the current requirements for risk management $[8,9]$, but also the aspects of the sector $[7,10]$, whose definition is one of the main purposes of the article.

The result of the study is the authors' methodological approach to assessing the competitiveness of power companies, which allows to quickly identify industry risks and to assess their level of severity through the assessment of the value of these threats. The 
results are of practical importance and are used for the development strategies of power companies [1].

\section{RISK COMPONENT IN ASSESSING COMPETITIVENESS OF POWER GENERATING COMPANIES}

Currently, there are a vast number of opinions about understanding the essence and nature of risk in connection with the multidimensional nature of the phenomenon. Within the framework of the presented research with respect to its definition, risk is understood as the threat of loss of power companies' financial resources and their competitive advantages in the power market, which leads to the instability and uncertainty of the results of its economic activity.

Fundamentals of risk assessment and management in the modern power industry and especially the development of risk management in emerging economies were presented in several papers $[1,3,10]$. However, it is worth noting that, in general, the risk management system for power companies in developing economies is usually on a low basic level. This, in turn, leads to considerable difficulties in the process of analysis and management of existing threats and brings into focus the task of creating a methodological approach to industry-specific risk management.

\subsection{Industry-specific risks of power companies}

Based on decades of research $[4,5]$, the survey of the General and financial Directors of Russian power companies, as well as risk managers allowed us to identify a number of specific risks that are most important and crucial at the current stage of development. The results of the survey in the form of a list of risks arranged in groups are presented in Table 1.

\subsubsection{Preliminary assessment of sectoral risks of power generating companies}

The expert interviews allowed to carry out a preliminary analysis of the status of risks of power companies and to study the impact of the identified threats to the efficiency of the business and the degree of control these risks in a company [10].

The results are presented in Figs 1 and 2. According to which the exogenous risk associated with changes in the legislation carries the highest threat for the industry. About $83 \%$ of the respondents confirmed its high possibility. At the same time, the risk is noted as the least controlled (according to $4 \%$ of the experts). Along with the above-mentioned risk, experts identified a number of other factors (changes in market prices of electricity and capacity, reduced demand for electricity, etc.) that have the greatest adverse impact on the operations of power companies.

The least dangerous, according to experts, are risks such as the outflow of foreign capital $(0 \%$ - none of the experts noted that risk), inflation, currency rate instability (each of these risks was chosen by $5 \%$ of the experts) and climatic conditions (10\% of the experts), etc.

In terms of controllability (Fig. 2) the experts identify endogenous risks associated with the efficiency of the technology used, and institutional risks, reflecting the change in the price of primary and secondary (commodity) markets as the most controlled.

Presented results allow to draw up a risk map (Fig. 3), providing a comprehensive assessment of the identified risks taking into account the extent of their influence and level of risk-control in power companies. 
Table 1: Industry-specific risks of power companies in developing economies.

\begin{tabular}{|c|c|c|c|}
\hline No. & 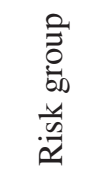 & Risk description & 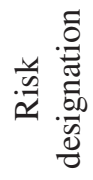 \\
\hline 1. & \multirow{5}{*}{ 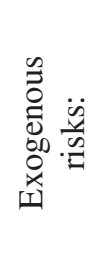 } & Regulatory risk & $R_{1}$ \\
\hline 2. & & General inflation risk & $R_{2}$ \\
\hline 3. & & Foreign capital outflow risk & $R_{3}$ \\
\hline 4. & & Climatic risk & $R_{4}$ \\
\hline 5. & & Environmental risk & $R_{5}$ \\
\hline 6. & \multirow{9}{*}{ 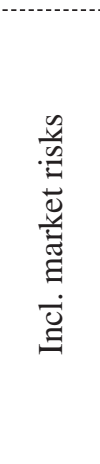 } & Tax risk & $R_{6}$ \\
\hline 7. & & Currency risk & $R_{7}$ \\
\hline 8. & & Power and power market prices risk & $R_{8}$ \\
\hline 9. & & Fuel market prices risk & $R_{9}^{\circ}$ \\
\hline 10. & & Limited fuel supply risk & $R_{10}$ \\
\hline 11. & & Limited electric power demand risk & $R_{11}$ \\
\hline 12. & & $\begin{array}{l}\text { Risk of limited demand for electric power delivery } \\
\text { services }\end{array}$ & $R_{12}$ \\
\hline 13. & & Coal market prices risk & $R_{13}$ \\
\hline 14. & & Limited coal supply risk & $R_{14}$ \\
\hline 15. & \multirow{5}{*}{ 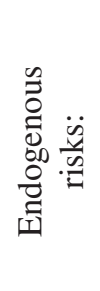 } & Operation and technical risk & $R_{15}$ \\
\hline 16. & & Risk of borrowing costs increase & $R_{16}$ \\
\hline 17. & & Liquidity risk & $R_{17}$ \\
\hline 18. & & Risk of loss of assets & $R_{18}$ \\
\hline 19. & & $\begin{array}{l}\text { Risk of incorrectness of mathematical models and their } \\
\text { implementation }\end{array}$ & $R_{19}$ \\
\hline 20. & \multirow{3}{*}{ 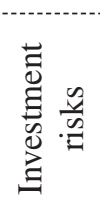 } & Risk of increase of expenses of investment projects & $R_{20}$ \\
\hline 21. & & $\begin{array}{l}\text { Risk of failure to meet time schedules of investment } \\
\text { projects }\end{array}$ & $R_{21}$ \\
\hline 22. & & Risk of lack of opportunities of funds raising & $R_{22}$ \\
\hline
\end{tabular}

The borderline in the centre of the risk map, divides it into two parts in accordance with the significance of the industry risks. A close allocation to this boundary value indicates a decline or increase of the risk depending on the initial threat level of the risk factor [1, 11]. Each of the zones of the risk-map is color-coded, reflecting the extent of the threat.

The left part represents less dangerous risks, the right part are the risks that have the greatest impact on the development of power companies.

Section 2.2.1 shows the preliminary assessment of risks for the power companies based on expert surveys and represents subjective judgment. However, the assessment of 


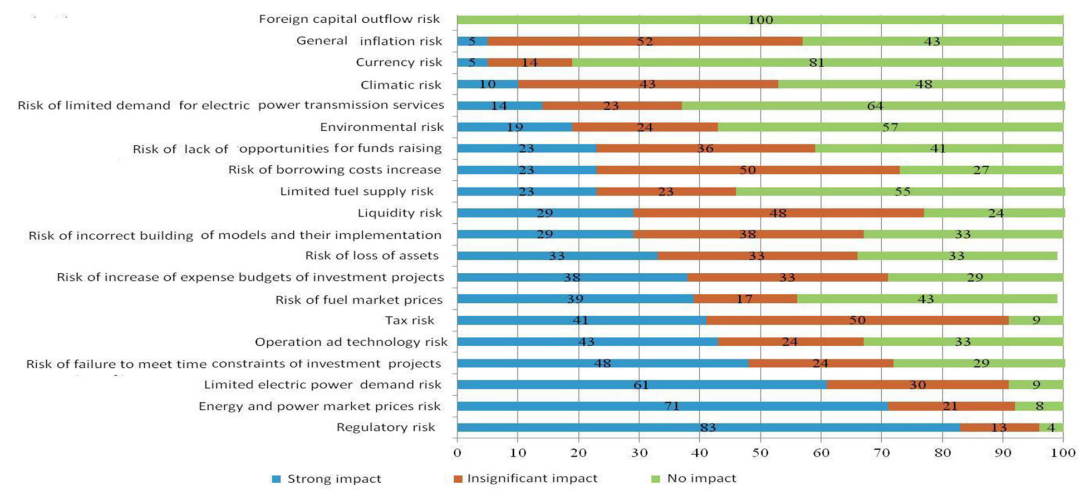

Figure 1: Level of risks impact on power companies' business by risk types, the percentage of surveyed experts.

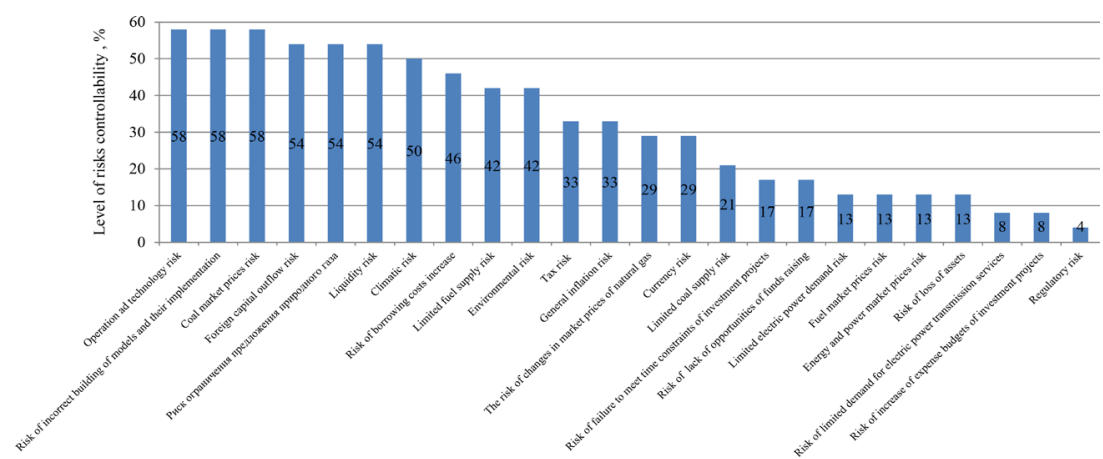

Figure 2: Risks controllability at power generating companies, the percentage of surveyed experts.

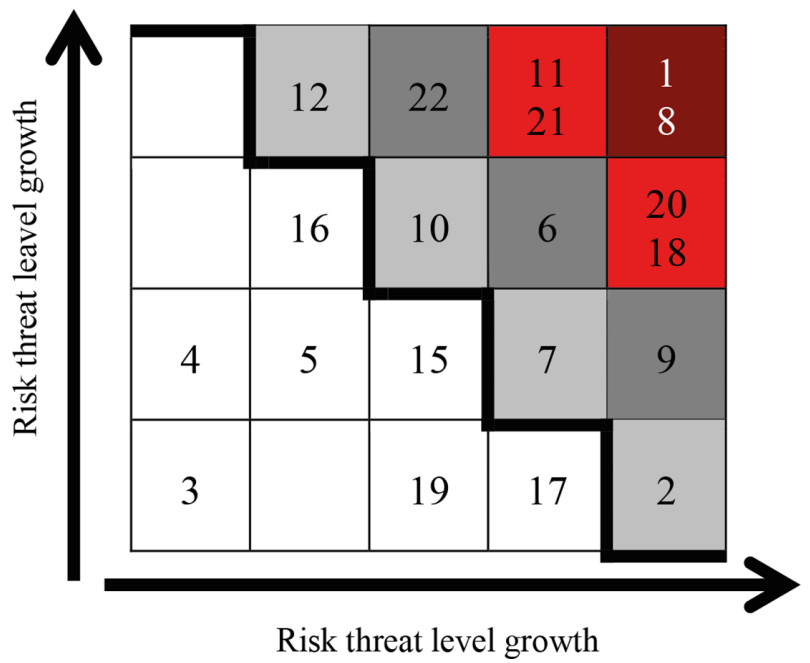

Figure 3: Risk map of power generating companies complex risks assessment. 
competitiveness, according to the authors, should base on objective assessments of relevant indicators and with considerations of the overall picture of the current level of identified threats.

In this study, the assessment of the competitiveness of a power generating company uses a model estimating cost of each risk and determining the total value of the required economic (risk) capital.

\section{ECONOMIC CAPITAL FACTOR IN ASSESSING COMPETITIVENESS OF POWER COMPANIES}

The authors have developed a methodological approach to the industry-specific risk-management of a power company using a common risk management concept of economic capital [6]. Economic capital is the amount of capital needed by the company to cover the risks it faces while maintaining a certain solvency level or in the event of a default [1]. In other words, economic capital allows power companies to maintain the current level of their independence and stability and to protect them against economic losses resulting from risks. Thus, economic capital determines the value the company must reflect to provide a certain level of investment attractiveness and long-term sustainability. Due to the fact that the Russian law does not categories economic capital, the presented requirements are met through existing company assets. In this study, the economic capital is calculated on the basis of VaR models for a given confidence level [12].

\subsection{Methodological approach to assessing economic capital}

The general scheme of the methodology for assessing the power industry risks the company and its economic capital is presented in Fig. 4 [1]. A detailed description of the proposed approach and the risk components considered by the authors in the original paper [1] and in the reference literature [11-16].

The final integrated assessment of the requirements of the economic capital of power companies, based on the variance-covariance method, is carried out according to the eqn (1) [16]:

$$
E C A P_{P G C}=\sqrt{\begin{array}{c}
E C A P_{i 1}^{2}+E C A P_{i 2}^{2}+E C A P_{i 3}^{2}+2 * E C A P_{i 1} * E C A P_{i 2} * \rho_{i 1, i 2}+ \\
2 * E C A P_{i 1} * E C A P_{i 3} * \rho_{i 1, i 3}+2 * E C A P_{i 2} * E C A P_{i 3} * \rho_{i 2, i 3}
\end{array}},
$$

where $E C A P_{P G C}$ is demand for economic capital of a power company; $E C A P_{i}$ is demand for economic capital with regard for i-th kind of risk; $\rho$ is a value of the correlation coefficient of preset risk indicators.

The practical significance of the presented calculations is that the total assessment value of economic capital shows the demand for capital of power companies that they need to have to maintain their financial stability in case of losses incurred from unexpected damage with a given level of probability.

\section{ASSESSMENT OF COMPETITIVENESS OF POWER GENERATING COMPANIES}

This section shows an example of evaluation of competitiveness of two Russian power companies, and developing strategies for their development through the use of the proposed methodological approach. Assessment of the economic capital of power company 1 has already been presented in the original paper [1]. However, when verifying its data, as well as 

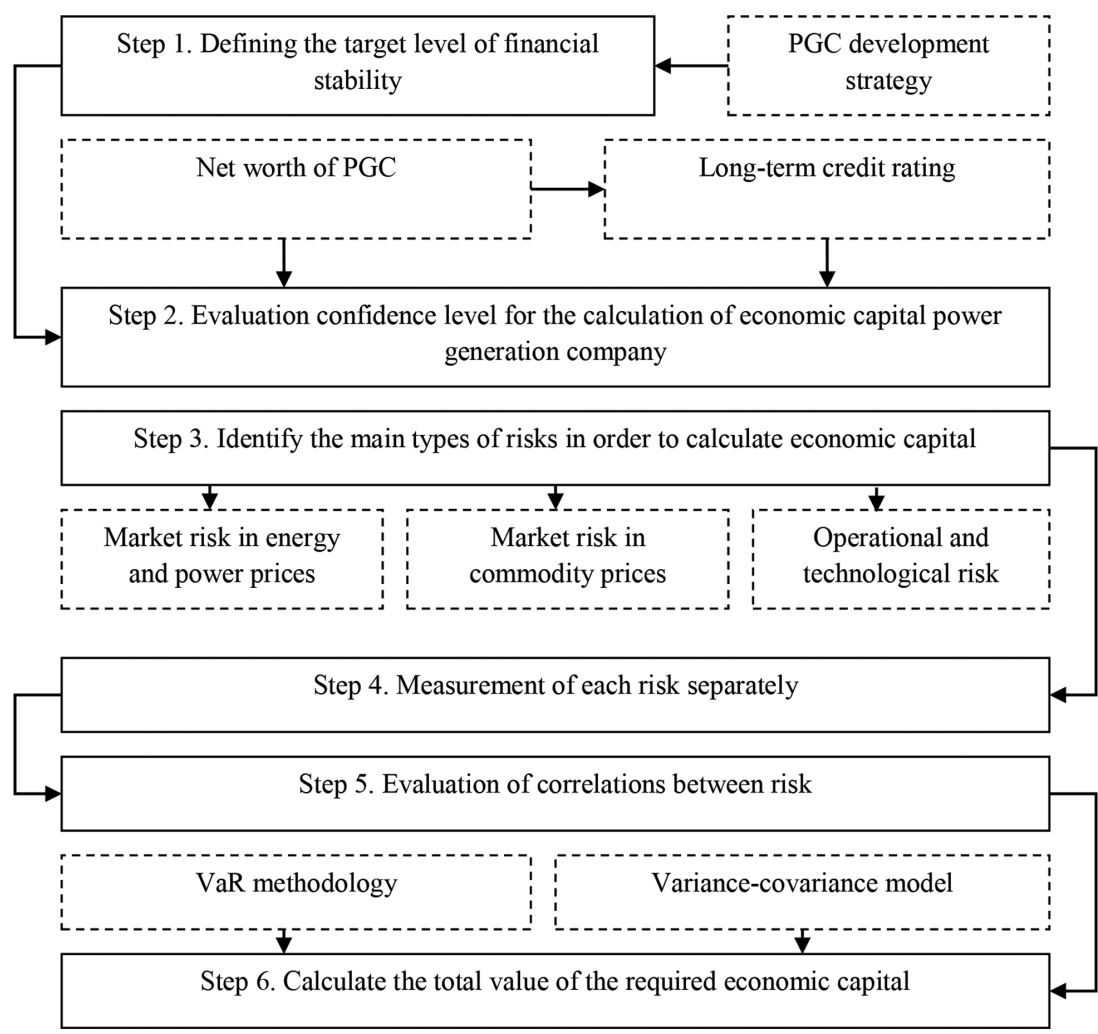

Figure 4: Methodology of power generating company risks assessment.

to carry out a comparative analysis of requirements to companies with different credit ratings, the authors performed additional research, adding performance indicators of Power Company 2 .

\subsection{Assessment of economic capital of a power company}

The main indicators reflecting the technical capacity and the financial activities of power companies are presented in Table 2.

The industry-specific risks of power companies examined as part of competitive assessment can be attributed to two large groups of risks. Market risks are part of exogenous risks (Table 1), and operational and technical risk is determined by the specific nature of a company's business (endogenous risk).

When measuring the value of these exogenous risks, a misconception may initially occur that these values will be the same or differ insignificantly from both companies. This is because power companies No. 1 and No. 2 sell power at prices set by the Moscow power exchange, and the risk of price changes in the commodities market is modeled on the basis of the dynamics of spot prices for natural gas traded on NYMEX. However, from a methodological perspective, the differences between the values of market risks using identical base data will be associated with set base values of the target credit rating, the confidence level of the power generating companies, the unit value, etc. 
Table 2: Source data for assessment: technical-economic and financial indicators of power generating companies.

\begin{tabular}{|c|c|c|}
\hline \multirow[b]{2}{*}{ Indicator } & \multicolumn{2}{|c|}{ Indicator value } \\
\hline & $\begin{array}{c}\text { Power company } \\
\text { No.1 }\end{array}$ & $\begin{array}{c}\text { Power company } \\
\text { No. } 2\end{array}$ \\
\hline \multicolumn{3}{|c|}{ Technical and economic indicators } \\
\hline Annual electric power output, thousand MWh & 20,000 & 40,000 \\
\hline Fuel consumption (gas - 100\%), million $\mathrm{m}^{3}$ & 15,000 & 22,000 \\
\hline \multicolumn{3}{|c|}{ Financial indicators } \\
\hline Revenues for fiscal year, million USD & 70 & 79 \\
\hline Net profit for fiscal year, million USD & 2 & 3.5 \\
\hline Assets, million USD & 53 & 63 \\
\hline Own capital, million USD & 25 & 31 \\
\hline Target-oriented credit rating: & BBB & A \\
\hline Confidence level, \% & 99.70 & 99.84 \\
\hline
\end{tabular}

Table 3: Economic capital estimation based on studied sample of risk factors for Power company No. 1.

\begin{tabular}{|c|c|c|c|c|c|c|c|}
\hline Indicator & $k_{99,70}$ & $\sigma$ & $\mathrm{V}$ & $\mathrm{T}$ & VaR & EL & ECAP \\
\hline$E C A P_{8}$ & 2.27 & 2.91 & 50,000 & 90 & $3,133,358.63$ & $1,562,269.12$ & $1,571,089.51$ \\
\hline$E C A P_{9}$ & 2.27 & 0.57 & 12,000 & 90 & $147,300.2$ & $58,630.1$ & $88,670.06$ \\
\hline \multirow[t]{2}{*}{$E C A P_{15}$} & - & - & - & - & $610,284.4$ & $502,214.43$ & 108,070 \\
\hline & \multicolumn{6}{|c|}{ General demand for company's economic capital, USD } & $1,510,070$ \\
\hline
\end{tabular}

Table 4: Economic capital estimation based on studied sample of risk factors for Power company No. 2.

\begin{tabular}{|c|c|c|c|c|c|c|c|}
\hline Indicator & $k_{99,84}$ & $\sigma$ & $\mathrm{V}$ & $\mathrm{T}$ & VaR & EL & ECAP \\
\hline$E C A P_{8}$ & 2.58 & 1.58 & 90,000 & 90 & $3,480,491.34$ & $524,145.22$ & $2,956,346.12$ \\
\hline$E C A P_{9}$ & 2.58 & 0.99 & 21,000 & 90 & $508,856.64$ & $147,257.19$ & $361,599.45$ \\
\hline$E C A P_{15}$ & - & - & - & - & $525,981.12$ & $344,129.42$ & $181,851.7$ \\
\hline
\end{tabular}

Operational and technical features of companies determine substantial differences in the demand for economic capital. The valuation of this risk is based on a retrospective data study of the companies for a given area of operation.

Based on the analysis of initial data [1] and comprising a correlation matrix between risks, the following requirements for each of the risks were obtained as shown in Tables 3 and 4. 
Therefore, comparing the results from Tables 3 and 4 to ensure financial stability and competitiveness in the current credit rating, the power generating companies should have the estimated amount of capital.

As seen from Table 2, the current financial position of each of the power generating companies allows meeting the demand for risk coverage. It is possible because the own capital amounts for every company are bigger than value of companies economic capital demand.

\subsection{Improving competitiveness of power generating companies}

This section describes the main reasons for increasing demands to capital to cover risks of power companies, as well as the increasing level of competitiveness, and investment attractiveness and financial stability of companies.

\subsubsection{Increasing requirements for economic capital of power companies}

Comparative analysis of performed calculations showed that the demand for economic capital of Power generating company No. 2 exceeds that of company No. 1 by 2.32 .

This primarily reflects a higher cumulative industry-specific risk in company No. 2. Moreover, in the subsequent development, including implementation of investment projects, the named Power company will need to attract more funds to cover unexpected losses when a risk occurs (at full or partial default).

One of the main causes of the identified significant difference in the requirements of power companies with regard to risk is related to the international target-oriented credit rating assigned to them. Its value directly affects the value of the confidence level of the power companies. In accordance with the International rules of risk management, the requirements as to the size of economic capital are much stricter for the most sustainable (in accordance with the rating) companies (Domnikov [8]). In practice, when comparing the confidence factor (k) calculated for each power generating company (Tables 3 and 4), it may be seen that a larger value of the coefficient corresponds to a greater level of confidence.

Another main reason for increased requirements is underestimation of average expected losses from each kind of risk (EL) by the company of average expected losses from each kind of risk (EL). The mean value of forecast error for Power company No. 1 is $43 \%$ (Table 3 ) with the maximum value of $60 \%$, while a similar indicator for company No. $264 \%$ with the maximum value of $85 \%$ (Table 4 ).

In addition to these major causes of the results obtained, a number of other causes associated with the deterioration of the financial situation, the quality and reliability of the services provided, etc. may be named as well.

\subsubsection{Strategy to increase competitiveness of power companies}

Development of directions to increase competitiveness of a power company is one of the most difficult and important issues on the way of development of a company, and of the power business in general.

However, this process is impossible without the liberalization of the power sector as a global trend, which promotes the transition to an open competitive power and power market (Gitelman [12]).

In terms of technology, competitiveness must be supported with the introduction of innovative technologies, including those in the field of power saving, smart power networks, alternative power sources, development of decentralized power systems, etc. 
In the economic aspect, an absolute factor of competitive growth of power companies is the necessity to raise its commercial efficiency by reducing production costs and improving the quality of customer service.

However, risk management sets specific requirements for improving competitiveness of power companies. A comprehensive preliminary analysis based on the current rules and methods of risk management and an effective forecasting system would allow to establish the most significant risks in the company's activities and to identify their threat level. In addition, timely implementation of targeted risk management programs will provide an opportunity to neutralize the current risk level and to minimize the integral indicator of competitiveness.

As part of this methodology risks assessment is carried out by measuring their value. Therefore, the reduction in risk cost contributes to the reduction of the cumulative value of the required economic capital of a power company and an increase of its competitiveness.

\section{CONCLUSIONS}

At present, high levels of instability, volatility and the procyclicality of development of power markets characterize the emerging economies. Dependence on the global financial system, global power markets and commodity markets brings forth industry specific risks characterized by a high level of latency. As a consequence, the emerging threats in the form of financial and non-financial losses require an effective risk management system with a main objective to identify and measure potential threats, and eventually improve the competitiveness of the national power business.

The results of the study have contributed to the expansion of the methodological framework of assessment of power companies' competitiveness. The risk-based approach is the basis for the creation and development of industry-specific risk management. The main advantage of this approach is a cumulative account of not only technical and economic indicators, but also an overall (general) assessment of the company's place in the market through the use of international target credit ratings.

The main practical achievement of the study is the investigation and analysis of industry-specific risks of power companies and assessment of economic capital as an indicator of competitiveness. Apart from this, the main directions for the strategy of competitiveness development, long-term stability and investment attractiveness of the power company were defined. The main disadvantages, determining the prospects for future work in this direction are the lack of formalized assessments of losses caused by other risks, having which would allow to improve the accuracy and quality model. Secondly, an improvement would involve better ways of assessment of economic capital, by separating industry-specific risks and their accumulation, specifically under abnormal cost distribution conditions. Thirdly, industry-specific risk assessment and management presumes consideration and use of a greater number of strategic directions of development of power facilities. In addition to financial stability, it is necessary to assess production and investment factors affecting the competitiveness of the business.

\section{REFERENCES}

[1] Domnikov, A., Khomenko, P. \& Chebotareva, G., A risk-oriented approach to capital management at a power generation company in Russia. Proceeding of the 5th International Conference on Power and Sustainability, eds. H.H. Al-Kayiem, C.A. Brebbia \& S.S. Zubir, WIT Transactions on Ecology and the Environment: Southampton, Boston, pp. 13-24, 2014.

http://dx.doi.org/10.2495/esus140021 
[2] Zucker, A. \& Hinchliffe, T., Optimum sizing of PV-attached electricity storage according to power market signals - a case study fog Germany and Italy. Applied Power, 127, pp. 141-155, 2014.

[3] Domnikov, A., Chebotareva, G. \& Khodorovsky, M., Development of risk management for power generating companies in developing countries. Proceeding of the 7 th International Conference on Sustainable Development and Planning, eds. O. Ozsevik, C.A. Brebbia \& S.M. Sener, WIT Transactions on Ecology and the Environment: Southampton, Boston, pp. 859-870, 2015. http://dx.doi.org/10.2495/sdp150721

[4] Domnikov, A., Chebotareva, G. \& Khodorovsky, M., Evaluation of investor attractiveness of power-generating companies: special reference to the development risks of the electric power industry. Proceeding of the 1st International Conference on Power Production and Management in the 21st Century: the Quest for Sustainable Power, eds. C.A. Brebbia, E.R. Magaril \& M.Y. Khodorovsky, WIT Transactions on Ecology and the Environment: Southampton, Boston, pp. 199-210, 2014.

http://dx.doi.org/10.2495/eq140211

[5] Domnikov, A., Chebotareva, G. \& Khodorovsky, M., Evaluation of investor attractiveness of power-generating companies, given the specificity of the development risks of electric power industry. Vestnik UrFU, 3, pp. 15-25, 2013.

[6] Domnikov, A., Chebotareva, G., Khomenko, P. \& Khodorovsky, M., Risk-oriented approach to long-term sustainability management for oil and gas companies in the course of implementation of investment projects. Proceeding of the 10th International Conference on Ecosystems and Sustainable Development, eds. J.L. Miralles i Garcia \& C.A. Brebbia, WIT Transactions on Ecology and the Environment: Southampton, Boston, pp. 275-284, 2015. http://dx.doi.org/10.15826/vestnik.2015.14.4.035

[7] Gitelman, L.D. \& Ratnikov, B.E, (eds). Power Business, Delo: Moscow, 2006.

[8] Proposed Enhancements to the Basel II framework. Technical Document: Basel Committee on Banking Supervision, available at: www.bis.org

[9] International regulatory framework for banks. Technical Document: Basel Committee on Banking Supervision, available at: www.bis.org

[10] Market Risk Management in Russian electricity companies. Analytical study; KPMG Agency. Office of Russian and CIS researches, available at: https://www.kpmg.com/ RU/ru/IssuesAndInsights/ArticlesPublications/Documents/Market-risk-managementat-Russian-power-companies-rus.pdf

[11] Gmurman, V., Probability Theory and Mathematical Statistics, Higher School: Moscow, pp. 28-55, 1997.

[12] Sakaguchi, J., Miyauchi, H. \& Misawa T., Risk assessment of power plant investment by three level ordered probit model considering project suspension. SQR Press, 1, pp. 22-29, 2013. http://dx.doi.org/10.1109/irep.2013.6629398

[13] RiskMetrics. Technical Document: Morgan Guaranty Trust Company, available at: http://www.macs.hw.ac.uk/ mcneil/F79CR/CMTD1.pdf

[14] Peter, C., Estimating Loss Given Default - Experiences from Banking Practice, Springer-Verlag: Berlin Heidelberg, pp. 151-183, 2011. http://dx.doi.org/10.1007/978-3-642-16114-8_9

[15] Ryzin, V, (eds), Classification and Cluster, Mir: Moscow, 1980.

[16] Ohlson, J.A., Financial ratios and the probabilistic prediction of bankruptcy. Journal of Accounting Research, 18(1), pp. 109-131, 2012.

http://dx.doi.org/10.2307/2490395 